\title{
Mesenchymal stem cells for the treatment of ulcerative colitis: a systematic review and meta-analysis of experimental and clinical studies
}

\author{
Xiao Shi ${ }^{1,3}$, Qi Chen ${ }^{2}$ and Fen Wang ${ }^{1,3^{*}}$ (1)
}

\begin{abstract}
Objective: To explore the promising use of mesenchymal stem cells (MSCs) for ulcerative colitis (UC).

Methods: Studies reporting MSC treatment on UC were searched on five databases. Methodological quality was assessed based on the SYRCLE's Risk of Bias (RoB) tool and MINORS tool. Data analysis was conducted using Engauge Digitizer 10.8 and Stata 14.0.

Results: A total of 15 studies met the inclusion criteria including 8 animal $(n=132)$ and 7 human $(n=216)$ trials. In animal studies, mice treated with MSCs had significantly lower disease activity index (DAI) than that in the control group: the 1st day (standardized mean difference (SMD) $-0.753, p=0.027)$, the $3 \mathrm{rd}$ day (SMD $-1.634, p=0.000$ ), the 5th day (SMD $-2.124, p=0.000)$, the 7th day (SMD - 5.327, $p=0.000)$, the 9th day (SMD $-2.979, p=0.000)$, and the 14th day (SMD $-5.032, p=0.000)$. Lower histopathological score (HS) (SMD $-5.15, p<0.05)$ and longer colon length (SMD 2.147, $p=0.001$ ) in mice treated with MSCs were also indicated. The main outcome in clinical trials showed, compared with control group, healing rate of patients accompanied by MSC therapy elevated obviously: MSCs vs 5-aminosalicylic acids (5-ASA) $(\mathrm{RR}=2.317, p=0.000)$ and MSCs + 5-ASA vs placebo + 5-ASA $(\mathrm{RR}=5.118)$. The analytical data in 4 trials conducted with single-arm studies also demonstrated increased healing rate $(0.787)$ after MSC treatment $(p=0.000)$.
\end{abstract}

Conclusion: Our meta-analysis results supported that MSCs could be an underlying method of treating UC.

Keywords: Mesenchymal stem cells, Ulcerative colitis, Systematic review and meta-analysis, Animal studies, Clinical trials, Disease activity index, Histopathological score, Colon length, Healing rate

\section{Introduction}

Ulcerative colitis (UC) is a chronic, idiopathic inflammation of the large intestine (colon), which is classified as a form of inflammatory bowel disease (IBD) [1]. It is characterized by suffering from a relapsing and remitting course [2]. Both male and female are affected equally, specially adults aged $30-40$ years [3]. The incidence of $\mathrm{UC}$ has been

\footnotetext{
* Correspondence: wfen-judy@csu.edu.cn

'Department of Gastroenterology, The Third Xiangya Hospital, Central South University, Changsha 410013, Hunan, People's Republic of China

${ }^{3}$ Department of Gastroenterology, Hunan Key Laboratory of Non-Resolving Inflammation and Cancer, The Third Xiangya Hospital, Central South University, 138 Tongzi Road, Changsha 410013, Hunan, People's Republic of China

Full list of author information is available at the end of the article
}

increasing around the world. The highest annual incidence reported was 24.3 per 100,000 person-years in Europe, 6.3 per 100,000 person-years in Asia and the Middle East, and 19.2 per 100,000 person-years in North America [4]. In patients with UC, ulcers and inflammation of the inner lining of the colon could incur symptoms of abdominal pain, diarrhea, and rectal bleeding [5]. The exact cause of UC remains unknown. Current studies have shown that abnormal activation of the immune system, hereditary susceptibility and alteration of intestinal flora caused by mucosal barrier defects may play a role in the pathophysiology of UC [6-8].

The existing clinical managements include conventional medications, endoscope therapy, and surgery

(C) The Author(s). 2019 Open Access This article is distributed under the terms of the Creative Commons Attribution 4.0 International License (http://creativecommons.org/licenses/by/4.0/), which permits unrestricted use, distribution, and 
treatment. Majority of UC patients would be subject to medications including anti-inflammatory agents such as 5aminosalicylic acids (5-ASA), systemic corticosteroids, and topical corticosteroids, as well as immunomodulators like azathioprine, 6-mercaptopurine (6-MP), cyclosporine, and methotrexate [9]. Unfortunately, it is difficult to cure UC completely, with $74 \%$ of patients experiencing at least one relapse during 5-year observation in a prospective population-based cohort study [10]. A meta-analysis conducted by Ford et al. [11] has shown that $887(60.3 \%)$ of 1470 UC patients fell short of achieving remission in randomized to receive 5-ASA, indicating that more than half of UC patients may not be able to have a positive response to traditional medications. What is more, taking these drugs could lead to the occurrence of various adverse effects [12]. The use of corticosteroids is confirmed to be associated with cutaneous effects, weight gain, hyperglycemia, osteoporosis, adrenal insufficiency, and cataracts [13]. Moreover, corticosteroid therapy is capable of increasing risk of opportunistic infections, especially when administered in combination with other immunosuppressive drugs [14]. The intolerance or potential occurrence of myelotoxicity and hepatotoxicity generated by immunomodulators could make nearly one fourth of patients discontinue the treatments $[15,16]$. Therefore, new therapeutic targets are required in order to achieve ameliorative efficacy without a risk of incontinence.

Mesenchymal stem cells (MSCs) are one of the most popular multipotent stem cells which have been widely explored over the past few decades [17]. MSCs have shown therapeutic effects in various inflammatory diseases and kidney transplantation due to its hypoimmunogenic and immunoregulatory properties [1822]. MSCs could be easily isolated and amplified from the bone marrow and other tissues [23, 24]. Previous reviews have demonstrated that MSCs could regulate innate and adaptive immune responses by releasing various mediators, including immunosuppressive molecules, growth factors, exosomes, chemokines, complement components, and multiple metabolites, when exposed to inflammatory environment, thus promoting the repair and regeneration of damaged tissues [25].

The first animal experiment to investigate MSCs for treatment of UC mouse model was conducted in 2006. The results showed that bone marrow-derived MSCs played a role in repairing injured intestinal mucosa, as well as downregulating the immune function of $\mathrm{T}$ cells [26]. In 2009, the successful application of MSCs in UC patients was reported for the first time [27]. However, there are scarce large-scale prospective trials that could convincingly evaluate the efficiency and safety of MSC as a candidate therapeutic strategy for UC. As such, the objective of our study was to perform a systematic review and meta-analysis of animal and clinical studies on the treatment of UC with MSCs.

\section{Material and methods \\ Search strategy}

A comprehensive search was performed in electronic database as follows: PubMed, EMBASE, the Cochrane Library of Systematic Reviews, Web of Science, and China National Knowledge Infrastructure. Free text words and database-specific index terms were combined with Boolean operators (" AND " and "OR ") to improve the sensitivity of our search. The identified studies were not constrained by publication date, language, or publication status. The following search strategy was applied: (Mesenchymal stem cells, Bone Marrow Stromal Cells, Mesenchymal Progenitor Cells, Mesenchymal Stromal Cells) AND (Ulcerative Colitis, Idiopathic Proctocolitis, Colitis Gravis). Retrieval strategy is shown in Additional file 1.

\section{Study selection}

All study selections were conducted by two reviewers (Xiao Shi and Qi Chen) independently, with discrepancies discussed with the research group. We applied the following inclusion criteria: (1) published or unpublished single-arm studies, randomized controlled trial (RCT), or non-RCT with or without full texts; (2) included patients with UC; (3) animal trials with or without full texts; and (4) MSCs as a therapy for the treatment of UC without restricting the type of MSC, dose of cells, and the route of MSC administration. Exclusion criteria were as follows: (1) repeated studies, (2) no original research (reviews, editorials, non-research letters, protocols), (3) no separation of UC and Crohn's disease (CD), and (4) observational studies. Foreign language articles were translated by professional translation software when necessary. Articles of meetings were manually searched to ensure that they were published only in abstract forms.

\section{Data extraction}

Two independent authors (Xiao Shi and Qi Chen) evaluated titles and abstracts and resolved conflicts through discussion and consensus. Full texts were screened to extract all of the data from each eligible study. On the part of experiments in mice, the data contained the following: (1) first author; (2) year; (3) location; (4) mouse sex, strain, and weight; (5) number of each group; (6) modeling method; (7) modeling duration; (8) type and source of MSCs; (9) way of MSCs administrated; (10) times of treatment; and (11) parameter. For clinical trials, the data contained the following: (1) first author, (2) year, (3) location, (4) type of study, (5) number of MSCs group, (6) number of control group, (7) male/female, (8) age, (9) type and source of MSCs, (10) way of MSCs administrated, (11) outcomes, and (12) adverse events. 


\section{Assessment of study quality and bias}

Varying quality assessment tools were used to evaluate the bias risk of each enrolled study.

In terms of animal experiments, six parts including the title, abstract, introduction, methods, results, and discussion were explored using the SYRCLE's risk of bias (RoB) tool where the criteria contained 6 sorts of bias with 10 items. Each item contains several details and was classified as low, unclear, and high risk of bias [28]. The (MINORS) tool, involving 8 and 12 items for clinical trials with and without control groups respectively, was adopted to assess the quality of included clinical trials [29].

\section{Statistical analysis}

Disease activity index (DAI) was a potential factor to reflect the severity of UC, which involved the assessment of the character of stool and occult blood [30]. The morphological and pathological changes of UC could be represented by the evaluation of colon length and histopathological score (HS). Therefore, standardized mean difference (SMDs) and related 95\% CIs of DAI, colon length as well as HS in both treatment and control groups were retrieved in animal studies. For each human study, the outcome of healing rate (HR) was considered as the main endpoint. Odds ratios (ORs) and related 95\% CIs were calculated to compare treatment with control groups. For each eligible study, if the associated information was present merely in figures, two reviewers (Xiao Shi and Qi Chen) would use Engauge Digitizer 10.8 to collect data from the statistical graphs independently. Then, the mean values would be adopted [31]. For animal studies, there always existed huge differences in modeling duration and time point of intervention between different trials. In order to obtain comparability, the day of intervention was defined as the first day of data recording.

We evaluated the degree of heterogeneity between studies using inconsistency index $\left(I^{2}\right)$. Values of $I^{2}$ equal to 25,50 , and $75 \%$ were considered to indicate low, moderate, and high heterogeneity, respectively [32]. If $I^{2}<50 \%$, a fixed-effects model was applied; otherwise, a random-effects model was used [33]. With the purpose of exploring the sources of heterogeneity, all of the enrolled studies were sequentially excluded to demonstrate the overall impact of individual study and performed with subset analysis of time and treatment intervention afterwards where $I^{2}>50 \%$. Statistical meta-analysis was performed in STATA version 14.0 to generate forest plots of pooled ORs and SMDs with 95\% CIs.

\section{Results}

\section{Search results}

A total of 451 references were identified for review, of which 158 were excluded due to duplication. After reading through titles and abstracts, 270 studies were excluded for being irrelevant. Twenty-three possible full-text studies were carefully reviewed. Three clinical studies were excluded because of inappropriate result forms, and another 5 animal studies were excluded resulting from improper study designs. Ultimately, 7 human [34-40] and 8 animal studies [41-48] were selected for the meta-analysis (Fig. 1).

\section{Animal studies \\ Study characteristics}

A total of 132 mice were reported. C57BL mice made up $63.6 \%$ of the total number of mice used; BALB/C mice accounted for $36.4 \%$. Male mice accounted for $84.8 \%$, and female mice for the remaining $15.2 \%$. All of the 8 studies applied the same modeling method: UC mouse model was induced by receiving dextran sodium sulfate (DSS) drinking water instead of regular drinking water in control groups. Study characteristics are shown in Table 1.

\section{Quality of studies}

According to the SYRCLE's RoB tool, all of the animal studies were moderate to high for risk of bias. The SYRCLE risk of bias assessment revealed a low risk of $40 \%$, unclear risk of $21.3 \%$, and high risk of $38.7 \%$ among them.

Only 3 in 8 studies mentioned random sequence generation. It was hard to confirm the accurate baseline characteristics of mice in each group because none of the studies offered completed baseline information. It seemed that there is a lack of standard practice for allocation concealment and blinding of both study personnel and outcome assessors in all 8 studies. No study described any blindness so that both performance and detection bias were high. Attrition and reporting bias were low because outcomes in all 8 studies were clear and sufficient. The details can be found in Table 2 .

\section{$D A I$}

All of the 8 studies reported DAI; however, the data from Cao was excluded on account of the DAI was measured with mean level (0 days to 7 days), which was lack of comparability. We divided the time points of DAI assessment into six subgroups: $3(n=44), 3(n=52), 3$ $(n=40), 2(n=36), 2(n=24)$, and $3(n=52)$ studies belong to the 1st day, the 3rd day, the 5th day, the 7th day, the 9th day, and the 14th day, respectively. The randomeffects model and Cohen's method were used to assess the differences in DAI between the treatment group and control group. Subgroup results showed that the level of DAI was lower in the treatment group and there were significant differences between the two groups: the 1st day (SMD $-0.753,95 \% \mathrm{CI}-1.418$ to $-0.088, p=0.027$; $\left.I^{2}=83.0 \%, p=0.003\right)$, the 3rd day (SMD $-1.634,95 \% \mathrm{CI}$ 
-2.289 to $\left.-0.979, p=0.000 ; I^{2}=59.8 \%, p=0.083\right)$, the 5th day (SMD $-2.124,95 \%$ CI -3.083 to $-1.165, p=$ $0.000 ; I^{2}=90.9 \%, p=0.000$ ), the 7 th day (SMD -5.327 , $95 \% \mathrm{CI}-6.827$ to $-3.827, p=0.000 ; I^{2}=71.3 \%, p=$ 0.062 ), the 9 th day (SMD $-2.979,95 \% \mathrm{CI}-4.361$ to $\left.1.597, p=0.000 ; I^{2}=89.5 \%, p=0.002\right)$, and the 14th day $\left(\mathrm{SMD}-5.032,95 \% \mathrm{CI}-6.376\right.$ to $-3.689, p=0.000 ; I^{2}=$ $91.5 \%, p=0.000$ ) (Fig. 2). Studies were heterogeneous in each subgroup. To explore the sources of heterogeneity, linear regression was conducted, which suggested that the subgroup analysis could explain the heterogeneity by 44.83\% (Additional file 2: Table S1).

\section{Colon length}

Six of the 8 studies reported colon length $(n=104)$. We applied the random-effects model and Cohen's method to evaluate the differences in colon length between the treatment group and control group. The MSC experimental group demonstrated a clear increase in colon length compared to the control group (SMD 2.147, 95\% CI 0.830 to $3.463, p=0.001 ; I^{2}=84.8 \%, p=0.000$ ) (Fig. 3). Additionally, subgroup analysis based on administration routes was carried on. It was indicated that tail vein injection has a more stable outcome (SMD 2.830, 95\% CI 1.343 to $\left.4.316, p=0.000 ; I^{2}=75.0 \%, p=0.007\right)$ than intraperitoneal injection (SMD 0.871, 95\% CI -1.258 to $3.001, p=0.423 ; I^{2}=89.2 \%, p=0.002$ ) (Fig. 3). To explore the sources of heterogeneity, sensitivity analysis was performed by excluding studies sequentially. The results showed that after excluding the study by Park et al. [37] and Nam et al. [38], the heterogeneity decreased to low level $\left(I^{2}=0.000, p=98.5 \%\right)$ (Additional file 2: Table S2).

\section{Histopathological score}

Four of the 8 studies reported HS $(n=56)$. The randomeffects model and Cohen's method was applied to evaluate the differences in histopathological score between the treatment group and control group. The MSC experimental group cleared a significant decrease in $\mathrm{HS}$ compared to the control group (SMD - 5.15, 95\% CI 1.16 to $0.53, p<0.05 ; I^{2}=68.5 \%, p=0.023$ ) (Fig. 4). To explore the sources of heterogeneity, the studies were excluded in sequence. We noticed that by excluding the
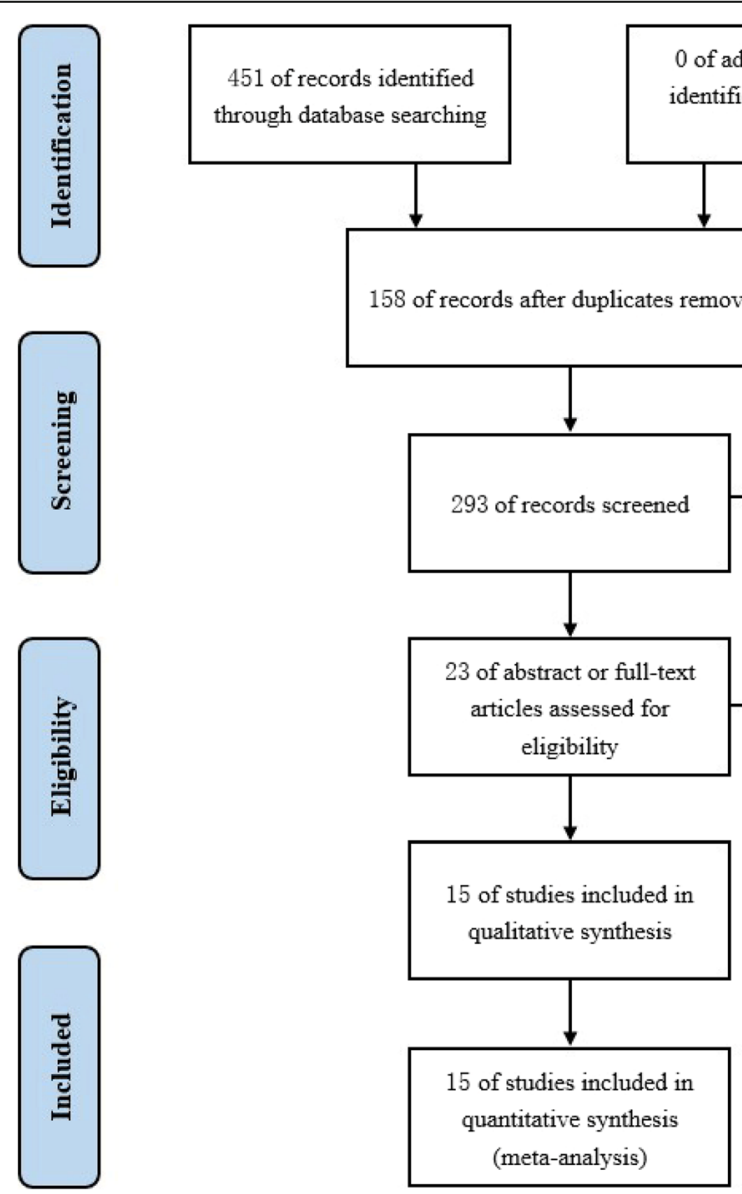

0 of additional records

identified through other

sources

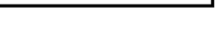

moved
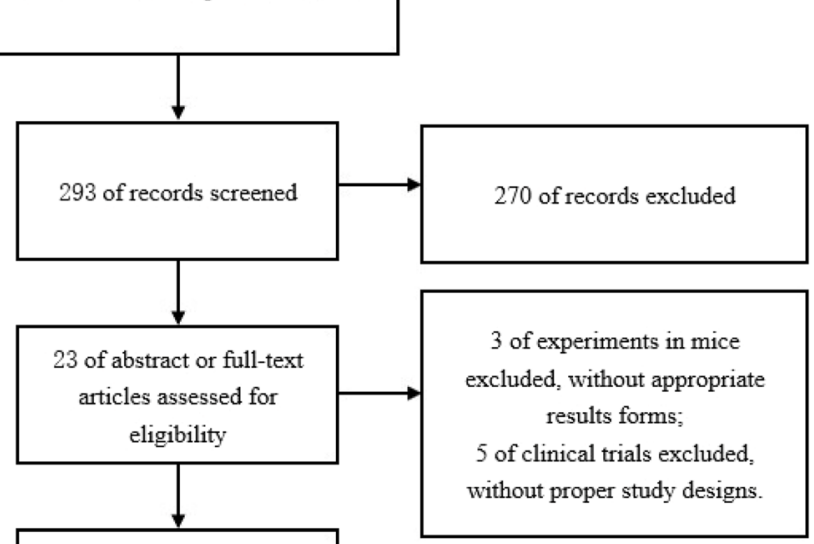

5 of studies included in

qualitative synthesis

5 of studies included in

(meta-analysis)

Fig. 1 Flow chart showing the meta-analysis study selection 
Table 1 Characteristics of mouse experiments

\begin{tabular}{|c|c|c|c|c|c|c|c|c|c|c|}
\hline $\begin{array}{l}\text { First } \\
\text { author }\end{array}$ & Year & Location & $\begin{array}{l}\text { Mice (sex, strain, } \\
\text { weight) }\end{array}$ & $\begin{array}{l}\text { Number of } \\
\text { each group }\end{array}$ & $\begin{array}{l}\text { Modeling } \\
\text { method }\end{array}$ & $\begin{array}{l}\text { Modeling } \\
\text { duration }\end{array}$ & $\begin{array}{l}\text { Type and } \\
\text { source of MSCs }\end{array}$ & $\begin{array}{l}\text { Way of MSCs } \\
\text { administrated }\end{array}$ & $\begin{array}{l}\text { Times of } \\
\text { treatment }\end{array}$ & Parameter \\
\hline $\begin{array}{l}\text { Guo- } \\
\text { Chao Niu }\end{array}$ & 2012 & China & $\begin{array}{l}\text { Male, C57B L/6, } \\
18 \sim 22 \mathrm{~g}\end{array}$ & $\begin{array}{l}\text { DSS + Vechile } \\
(n=10) \\
\text { DSS + MSCs } \\
(n=10)\end{array}$ & DSS (5\%) & 30 & $\begin{array}{l}\text { Mouse UC- } \\
\text { MSCs }\end{array}$ & $\begin{array}{l}\text { Tail vein } \\
\text { injection }\end{array}$ & 1 & $\begin{array}{l}\text { DAl, colon } \\
\text { length, HS }\end{array}$ \\
\hline $\begin{array}{l}\text { Xiao-Wen } \\
\mathrm{He}\end{array}$ & 2012 & China & $\begin{array}{l}\text { Male, BALB/c } \\
\text { mice, } 19-21 \mathrm{~g}\end{array}$ & $\begin{array}{l}\mathrm{DSS}+4 \% \mathrm{PBS} \\
(n=6) \\
\text { DSS }+\mathrm{MSCS} \\
(n=6)\end{array}$ & DSS (4\%) & 7 & $\begin{array}{l}\text { Mouse BM- } \\
\text { MSCs }\end{array}$ & $\begin{array}{l}\text { Tail vein } \\
\text { injection }\end{array}$ & 3 & $\begin{array}{l}\text { DAl, colon } \\
\text { length, HS }\end{array}$ \\
\hline $\begin{array}{l}\text { Xiao-Xi } \\
\text { Xu }\end{array}$ & 2018 & China & $\begin{array}{l}\text { Male, BALB/C } \\
\text { mice, } 18-22 \mathrm{~g}\end{array}$ & $\begin{array}{l}\text { DSS }+4 \% \mathrm{PBS} \\
(n=8) \\
\text { DSS + ERCS } \\
(n=8)\end{array}$ & DSS (3\%) & 7 & Mouse ERCs & $\begin{array}{l}\text { Tail vein } \\
\text { injection }\end{array}$ & 3 & $\begin{array}{l}\text { DAl, colon } \\
\text { length }\end{array}$ \\
\hline $\begin{array}{l}\text { Jin Seok } \\
\text { Park }\end{array}$ & 2015 & Korea & $\begin{array}{l}\text { Male, C57BL/6 } \\
\text { mice, N/A }\end{array}$ & $\begin{array}{l}\text { DSS + PBS } \\
(n=8) \\
\text { DSS + mc- } \\
\text { MSCs }(n=8)\end{array}$ & DSS (2.5\%) & 6 & MC-MSCS & $\begin{array}{l}\text { Tail vein } \\
\text { injection }\end{array}$ & 3 & $\begin{array}{l}\text { DAl, colon } \\
\text { length, HS }\end{array}$ \\
\hline $\begin{array}{l}\text { Young- } \\
\text { Sun Nam }\end{array}$ & 2015 & $\begin{array}{l}\text { South } \\
\text { Korea }\end{array}$ & $\begin{array}{l}\text { Female, C57BL/ } \\
6, \text { N/A }\end{array}$ & $\begin{array}{l}\text { DSS + PBS } \\
(n=10) \\
\text { DSS }+ \text { MSCs } \\
(n=10)\end{array}$ & DSS (3.5\%) & 6 & $\begin{array}{l}\text { Mouse BM- } \\
\text { MSCs }\end{array}$ & $\begin{array}{l}\text { Intraperitoneal } \\
\text { injection }\end{array}$ & 1 & $\begin{array}{l}\text { DAl, colon } \\
\text { length }\end{array}$ \\
\hline $\begin{array}{l}\text { Wei-Xin } \\
\text { Liu }\end{array}$ & 2015 & China & $\begin{array}{l}\text { Male, C57BL/6 } \\
\text { mice, N/A }\end{array}$ & $\begin{array}{l}\text { DSS }(n=10) \\
\text { DSS + MSCS } \\
(n=10)\end{array}$ & DSS (N/A) & 7 & $\begin{array}{l}\text { Mouse BM- } \\
\text { MSCs }\end{array}$ & $\begin{array}{l}\text { Tail vein } \\
\text { injection }\end{array}$ & 1 & DAl \\
\hline Forte & 2015 & Italy & $\begin{array}{l}\text { Male, C57BL/6 } \\
\text { mice, N/A }\end{array}$ & $\begin{array}{l}\text { DSS }(n=4) \\
\text { DSS + MSCS } \\
(n=4)\end{array}$ & DSS (1.5\%) & 9 & $\begin{array}{l}\text { Human AD- } \\
\text { MSCs }\end{array}$ & Irrigation & 3 & DAl, HS \\
\hline Li Cao & 2019 & China & $\begin{array}{l}\text { Male, BALB/c } \\
\text { mice, } 21-23 \mathrm{~g}\end{array}$ & $\begin{array}{l}\text { DSS }+ \text { NS } \\
(n=10) \\
\text { DSS + EVS } \\
(n=10)\end{array}$ & DSS (3\%) & 7 & $\begin{array}{l}\text { EVs from } \\
\text { Mouse BM- } \\
\text { MSCs }\end{array}$ & $\begin{array}{l}\text { Intraperitoneal } \\
\text { injection }\end{array}$ & 7 & $\begin{array}{l}\text { DAl, colon } \\
\text { length }\end{array}$ \\
\hline
\end{tabular}

DSS dextran sodium sulfate, MSCS mesenchymal stem cells, PBS phosphate buffer saline, NS normal saline, EVs extracellular vesicles, ERCs endometrial regenerative cells, MC-MSCs mouse clonal MSCs, UC-MSCS umbilical cord MSCs, BM-MSCs bone marrow MSCs, AD-MSCs adipose-derived MSCs, DAI disease activity index, HS histopathological score

study conducted by Park et al. [37], the heterogeneity decreased to moderate level $\left(I^{2}=41.5 \%\right)$, which suggested the main source of the heterogeneity (Additional file 2: Table S3).

\section{Human studies}

\section{Description of studies}

A total of 216 patients were included. Of them, 139 received intravenous infusions, 33 adopted submucous injections through colonoscopy, and the remaining 44 were unclear. Study demographics and clinical characteristics are summarized in Table 3. Four of these studies were single-arm clinical trials, two were non-RCTs, and one was RCT. Remarkably, no serious adverse events were reported.

\section{Quality of studies}

The qualities of studies included in our analysis are shown in Table 3. Four studies are single-arm clinical trials with a maximum score of 16 points while the other 3 studies with control groups get a maximum score of 24 points. Only one study got access to high scores
(22 points), while the others did not. It was the lack of inclusion of consecutive patients, unbiased assessment of the study endpoint, and prospective calculation of sample size that might be attributed to. In total, the quality of clinical trials is poor.

\section{Clinical trials without the control group}

For 4 articles involved, the overall healing rate was 0.787 (95\% CI 0.715 to $0.867, p=0.000 ; I^{2}=77.8 \%, p=0.004$ ) among 117 patients with UC (Fig. 5).

\section{Clinical trials with the control group}

For 3 articles involved, a total of 99 patients with UC received MSCs, and 96 received conventional treatment. In accordance with varieties of study design, 2 subgroups were defined (MSCs vs 5-ASA and MSCs + 5-ASA vs placebo + 5-ASA). The healing rate in each subgroup was 0.791 and 0.853 , respectively. Our analysis showed that MSCs were associated with improved healing rate (HR) as compared with 5-ASA ( $\mathrm{RR}=2.317,95 \% \mathrm{CI}$ 1.591 to $3.375, p=0.000 ; I^{2}=0 \%, p=0.574$; Fig. 6) and MSCs + 5-ASA were also associated with improved 
Table 2 SYRCLE'S RoB tool for each experimental animal studies

\begin{tabular}{|c|c|c|c|c|c|c|c|c|c|c|}
\hline & $\begin{array}{l}\text { Random Sequence } \\
\text { Generation }\end{array}$ & $\begin{array}{c}\text { Baseline } \\
\text { Characteristics }\end{array}$ & $\begin{array}{l}\text { Allocation } \\
\text { Concealment }\end{array}$ & $\begin{array}{l}\text { Random } \\
\text { Housing }\end{array}$ & $\begin{array}{c}\text { Blinding } \\
\text { (Study Team) }\end{array}$ & $\begin{array}{c}\text { Random Outcome } \\
\text { Assessment }\end{array}$ & $\begin{array}{c}\text { Blinding (Outcome } \\
\text { Assessors) }\end{array}$ & \multirow{2}{*}{\begin{tabular}{|c|}
$\begin{array}{c}\text { Incomplete Outcome } \\
\text { Data }\end{array}$ \\
ATTRITION BIAS \\
\end{tabular}} & \multirow{2}{*}{$\begin{array}{c}\begin{array}{c}\text { Selective Outcome } \\
\text { Reporting }\end{array} \\
\text { REPORTING BIAS }\end{array}$} & \\
\hline & \multicolumn{3}{|c|}{ SELECTION BIAS } & \multicolumn{2}{|c|}{ PERFORMANCE BIAS } & \multicolumn{2}{|c|}{ DETECTION BIAS } & & & OTHER BIAS \\
\hline $\begin{array}{l}\text { Guo-Chao } \\
\text { Niu }\end{array}$ & & & & & & & & 4 & 4 & 4 \\
\hline $\begin{array}{c}\text { Xiao-Wen } \\
\mathrm{He}\end{array}$ & & & & & & & & 4 & 4 & 4 \\
\hline Xiao-Xi Xu & & & & & & & & 4 & + & + \\
\hline Jin Seok Park & & & & & & & & + & + & + \\
\hline $\begin{array}{c}\text { Young-Sun } \\
\text { Nam }\end{array}$ & & & & & & & & + & 4 & ㄴ \\
\hline Wei-Xin Liu & & & & & & & & 4 & 4 & 4 \\
\hline Forte & & & & 4 & (2) & 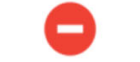 & (2) & 4 & 4 & 4 \\
\hline Li Cao & 8 & & & A & s & & (?) & 4 & 4 & 4 \\
\hline
\end{tabular}

\footnotetext{
Low risk of bias

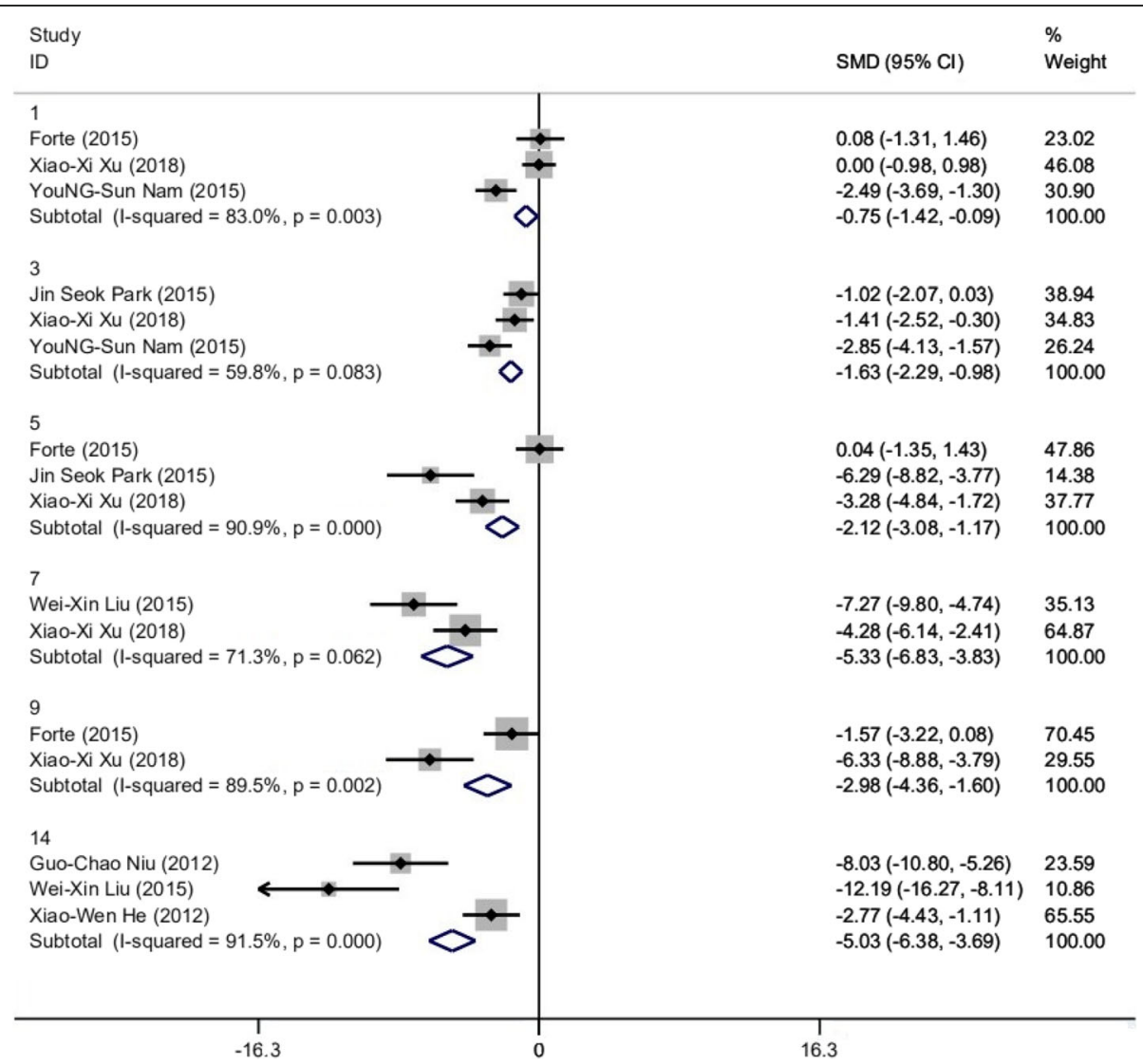

Fig. 2 Forest plot of mouse experiments about DAl 


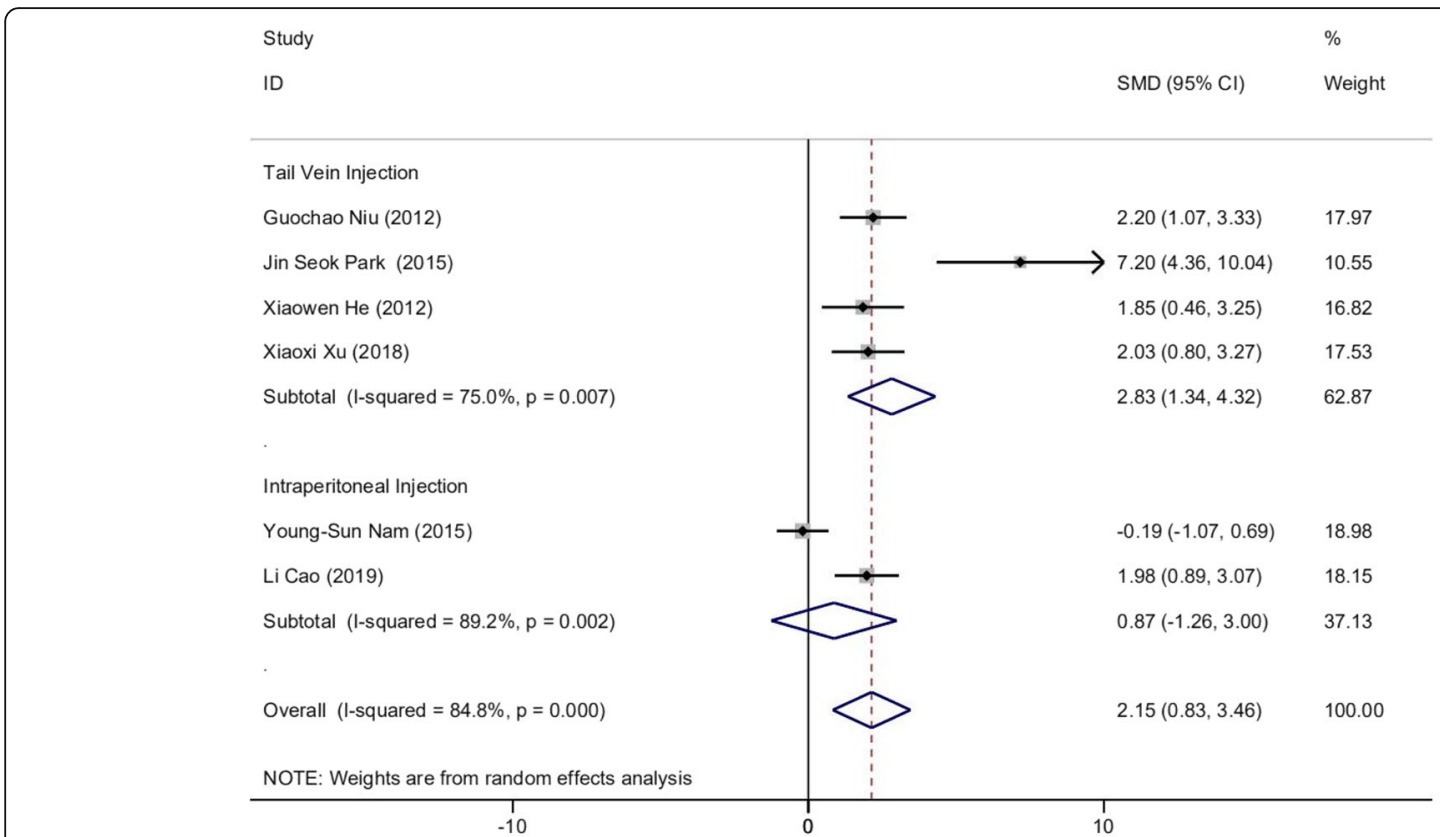

Fig. 3 Forest plot of mouse experiments on colon length

healing rate (HR) as compared with placebo + 5-ASA $(\mathrm{RR}=5.118,95 \% \mathrm{CI} 2.433$ to 10.765 ; Fig. 6).

\section{Discussion}

To the best of our knowledge, this is the first systematic review and meta-analysis to comprehensively summarize the efficiency of MSC in treatment with UC including both animal and clinical trials. Our results have demonstrated that both animal studies and human studies suggest that MSC has more significant therapeutic potential for UC mouse models or patients with UC, compared with conventional therapies.
In animal trials, our static analysis would still be unable to achieve a low heterogeneity on DAI $\left(I^{2}=44.83 \%\right)$ and HS $\left(I^{2}=41.50 \%\right)$ after performing subgroup analysis and linear regression. The possible explanations are presented as follows. Primarily, blindness was not described in all of the 7 studies, which may contribute to heterogeneity and bias. Secondly, UC mouse models were established by the administration of dextran sodium sulfate (DSS) with concentration ranging from 1.5 to $5 \%$. The duration of modeling was from 6 to 30 days. Thus, the differences of modeling could also be associated with heterogeneity. Plus, with regard to the sources of MSCs,

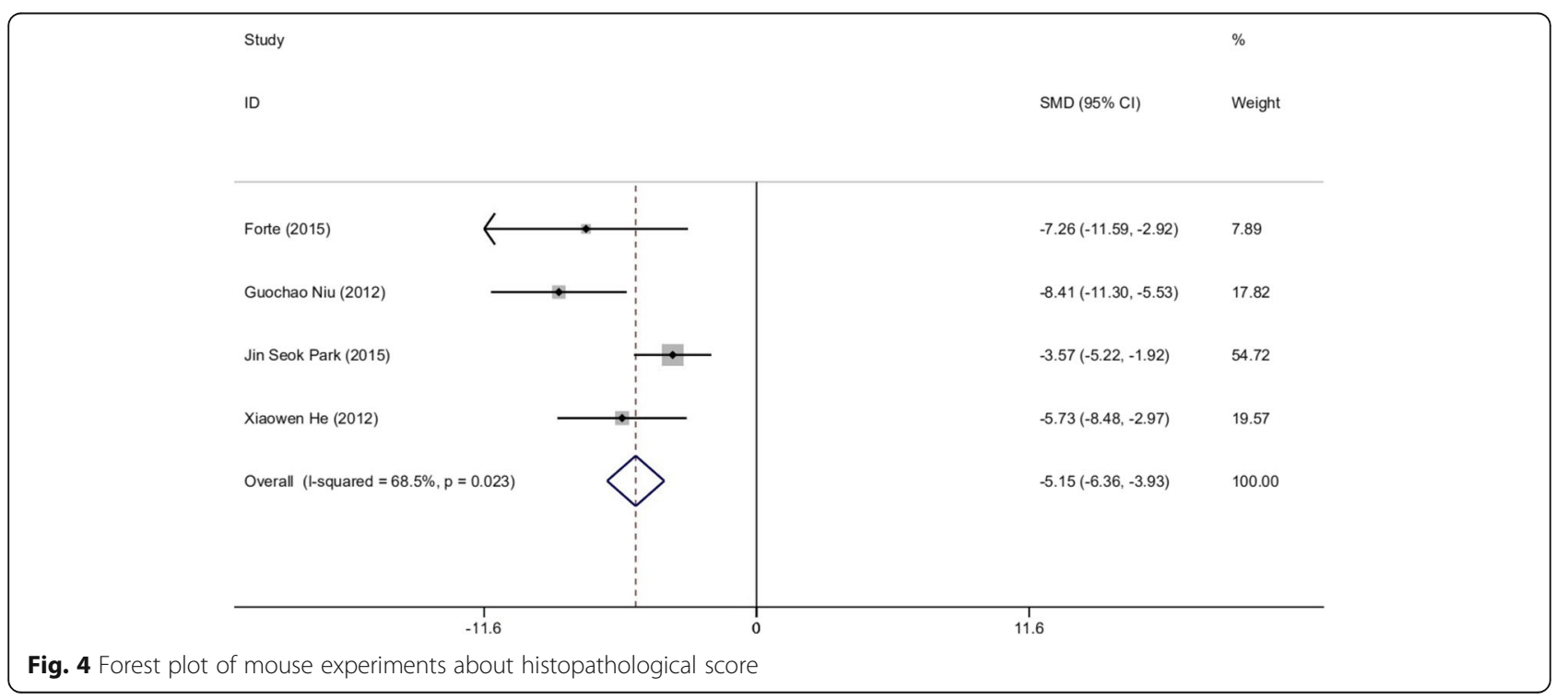


five of the seven animal studies used bone marrow MSCs (BM-MSCs) $(n=84)$, one applied umbilical cord MSCs (UC-MSCs) $(n=20)$, and another one adipose MSCs (AD-MSCs) $(n=8)$. There is no denying that more proper studies are required to regulate the modeling and implementation details of the intervention of UC to standardize animal experiments.

A meta-analysis conducted by Fold et al. has a failure to achieve remission in 724 (58.1\%) of 1247 patients randomized to receive 5-ASA, and the RR of failure to achieve remission with 5-ASA compared with placebo in active UC was 0.79 (95\% CI 0.71 to 0.88 ). It also seemed that the dose size of 5-ASA revealed no significance on the therapeutic effects $(p=0.13)$ [11]. The outcomes of a meta-analysis from Khan and colleagues suggested a trend for the benefits of azathioprine therapy (healing rate $=69.23 \%$ ), but it did not reach statistical significance $(\mathrm{RR}=0.85 ; 95 \% \mathrm{CI} 0.71$ to 1.01$)$ [49]. Compared with the placebo group, the healing rate of vedolizumab was statistically significant (OR $=2.51,95 \%$ CI 1.18 to 5.48 ) presented by Vickers and colleagues [50]. Two nonrandomized controlled studies included in our study figure out a significant efficacy of BM-MSCs versus 5-ASA control group (0.791, 95\% CI 0.696 to 0.887). Despite the absence of control groups in the remaining 4 singlearm studies, the healing rate of MSC therapy (0.787, 95\% CI 0.715 to 0.867 ) was higher than that of the above 5-ASA and azathioprine therapies. Due to the lack of data homogeneity compared with biological agents, more studies are needed for more sufficient evidence.
Apart from the efficiency of MSCs, greater importance should be attached to the safety issue. Of the seven human trials, no life-threatening adverse events were reported. In the study by Liang et al. [44], there were two patients suffering from low fever and insomnia after MSC infusion, respectively. Nevertheless, their symptoms restored quickly within 2 days without any medical intervention. Two kinds of MSCs were applied in our review where 182 patients with UC in six trials were treated with BM-MSCs; 34 patients in one trial accepted UC-MSCs. In consistence with the fact that the bone marrow (BM) has been the major source for the isolation of MSCs, but its invasive donation procedure and the reduction in life span of MSCs along with differentiation potential with growing age may cause injury [51, 52]. Compared with BM, although the successful separation rate of umbilical cord is relatively lower $(100 \%$ vs $63 \%$ ), it brings benefits in a less invasive method of being obtained, higher proliferation capacity, and lower colony frequency $(p<0.001)$ [53]. Findings from Shi et al. showed that the clinical application of MSCs derived from UC and adipose tissue has been increasing more than $30 \%$ as an alternative source in the past 10 years [25]. Taken together, future clinical applications should not merely be grounded in differentiation capacity, but also on the safety of the stem cells.

In terms of the administration routes of MSCs, which might also contribute to the tremendously various outcomes of MSC treatment, our results illustrated that both the delivery of intravenous injections and

Table 3 Characteristics of clinical trials

\begin{tabular}{|c|c|c|c|c|c|c|c|c|c|c|c|c|}
\hline $\begin{array}{l}\text { First } \\
\text { author }\end{array}$ & Year & Location & $\begin{array}{l}\text { Type of } \\
\text { study }\end{array}$ & $\begin{array}{l}\text { Number } \\
\text { of MSC } \\
\text { group }\end{array}$ & $\begin{array}{l}\text { Number } \\
\text { of control } \\
\text { group }\end{array}$ & $\begin{array}{l}\text { Male/ } \\
\text { female }\end{array}$ & Age & $\begin{array}{l}\text { Type and } \\
\text { source of } \\
\text { MSCs }\end{array}$ & $\begin{array}{l}\text { Way of MSCs } \\
\text { administrated }\end{array}$ & Outcomes & $\begin{array}{l}\text { Adverse } \\
\text { events }\end{array}$ & $\overline{\text { MINORS }}$ \\
\hline $\begin{array}{l}\text { Knyazev, } \\
\text { O. }\end{array}$ & 2017 & Russia & $\begin{array}{l}\text { Meeting } \\
\text { abstract }\end{array}$ & 26 & $\mathrm{~N} / \mathrm{A}$ & N/A & $\begin{array}{l}\text { 20-62 } \\
\text { (mean 28) }\end{array}$ & BM-MSCs & $\begin{array}{l}\text { Submucosal } \\
\text { injection by } \\
\text { colonoscopy }\end{array}$ & $\begin{array}{l}\text { One-year } \\
\text { healing rate } \\
23 / 26\end{array}$ & $\mathrm{~N} / \mathrm{A}$ & 9 \\
\hline Yang, Bo. & 2015 & China & Full text & 7 & 10 & $13 / 4$ & $37-62$ & BM-MSCs & $\begin{array}{l}\text { Submucosal } \\
\text { injection by } \\
\text { colonoscopy }\end{array}$ & $\begin{array}{l}\text { 14-month } \\
\text { healing rate } \\
7 / 7,3 / 10\end{array}$ & $\mathrm{~N} / \mathrm{A}$ & 16 \\
\hline $\begin{array}{l}\text { Lazebnik, } \\
\text { L. }\end{array}$ & 2011 & Russian & $\begin{array}{l}\text { Meeting } \\
\text { abstract }\end{array}$ & 44 & $\mathrm{~N} / \mathrm{A}$ & $\mathrm{N} / \mathrm{A}$ & $\mathrm{N} / \mathrm{A}$ & BM-MSC & $\mathrm{N} / \mathrm{A}$ & $\begin{array}{l}\text { One-year } \\
\text { healing rate } \\
32 / 44\end{array}$ & $\mathrm{~N} / \mathrm{A}$ & 9 \\
\hline Jun Liang & 2012 & China & Letter & 3 & $\mathrm{~N} / \mathrm{A}$ & $1 / 2$ & $\begin{array}{l}\text { 22-44 } \\
\text { (mean 29) }\end{array}$ & BM-MSC & $\mathrm{N} / \mathrm{A}$ & $\begin{array}{l}\text { One-year } \\
\text { healing rate } \\
2 / 3\end{array}$ & $\begin{array}{l}\text { N/A } \\
\text { Insomnia; } \\
\text { low; fever }\end{array}$ & 7 \\
\hline $\begin{array}{l}\text { Lazebnik, } \\
\text { L. }\end{array}$ & 2010 & Russian & $\begin{array}{l}\text { Meeting } \\
\text { abstract }\end{array}$ & 44 & $\mathrm{~N} / \mathrm{A}$ & $N / A$ & $\mathrm{~N} / \mathrm{A}$ & BM-MSC & $\begin{array}{l}\text { Intravenous } \\
\text { Infusions }\end{array}$ & $\begin{array}{l}\text { Two-year } \\
\text { healing rate } \\
34 / 44\end{array}$ & $\mathrm{~N} / \mathrm{A}$ & 9 \\
\hline $\begin{array}{l}\text { Knyazev, } \\
\text { Oleg }\end{array}$ & 2013 & Russian & $\begin{array}{l}\text { Meeting } \\
\text { abstract }\end{array}$ & 58 & 50 & N/A & $\begin{array}{l}\text { 19-64 } \\
\text { (mean 36) }\end{array}$ & BM-MSC & $\begin{array}{l}\text { Intravenous } \\
\text { Infusions }\end{array}$ & $\begin{array}{l}\text { One-year } \\
\text { healing rate } \\
44 / 58,17 / 50\end{array}$ & $\mathrm{~N} / \mathrm{A}$ & 16 \\
\hline $\begin{array}{l}\text { Jian-Xia } \\
\mathrm{Hu}\end{array}$ & 2016 & China & Full text & 34 & 36 & $\begin{array}{l}21 / 13 \\
22 / 14\end{array}$ & $\begin{array}{l}42.9 \pm 23.1 \\
\text { and } \\
43.7 \pm 28.7\end{array}$ & UC-MSCs & $\begin{array}{l}\text { Intravenous } \\
\text { infusions }\end{array}$ & $\begin{array}{l}\text { One-year } \\
\text { healing rate } \\
85.3 \%, 16.7 \%\end{array}$ & $\mathrm{~N} / \mathrm{A}$ & 22 \\
\hline
\end{tabular}




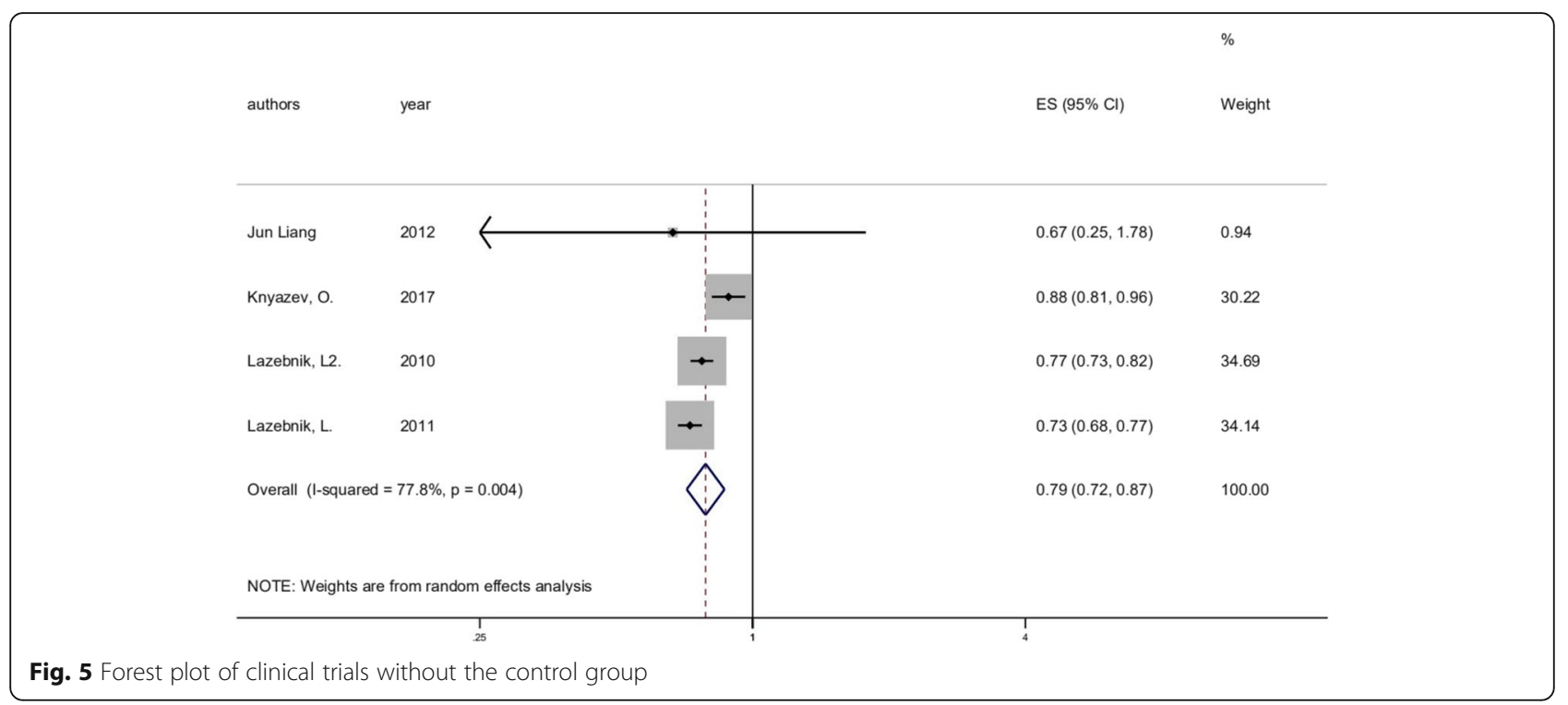

submucosal injection by endoscopy could be conducive to the healing and recurrence of UC [18]. It is also reported that submucosal endoscopic injection using ADMSCs could ameliorate TNBS-induced colitis, especially stenosis in rats [54]. Meanwhile, we have noticed from Nam and Cao's studies that compared with using entire mouse BM-MSCs, application of extracellular vesicles (EVs) extracted from mouse BM-MSCs was more efficient in improving colon length $[38,48]$. Since no trial has been implemented to compare manners of delivery, it remains unclear whether injected MSCs must migrate to sites of inflammation or whether they can exert their

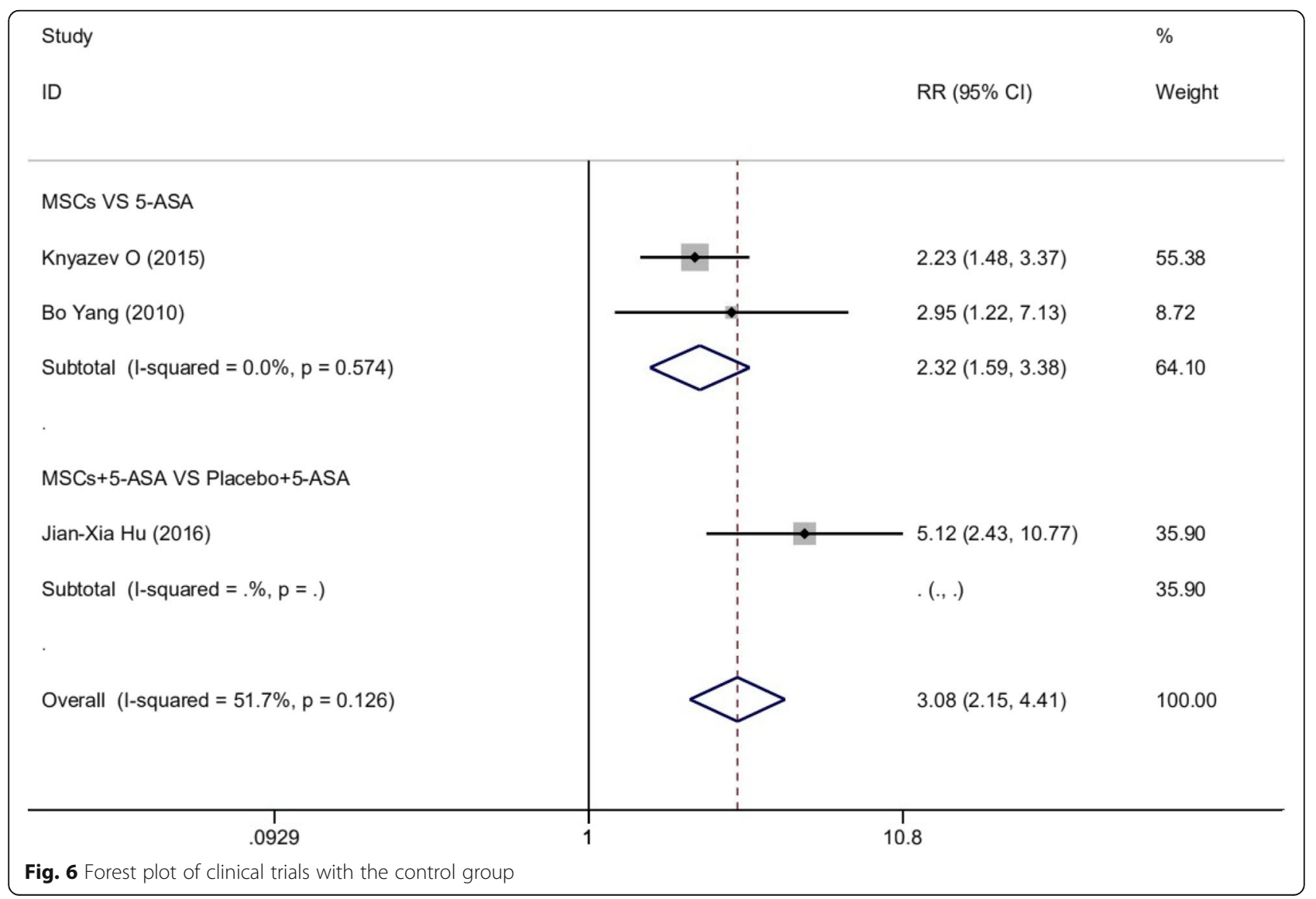


therapeutic effects in a systemic way. Lightner et al. [55] reported that the healing rates were higher when MSCs were combined with fibrin glue or a Gore Bio-A Fistula Plug compared with direct injection $(71 \%$ and $83 \%$ versus $50 \%)$. It seemed that intravenous, intraperitoneal and submucosal endoscopic injections are all feasible manners to put up significative outcomes in MSCs-therapy. Unfortunately, we were not able to determine which administration routes would occupy predominance due to the low quantity and quality of included literature. In consequence, more studies should be carried out to draw conclusions concerning which method is more reliable and effective.

Despite it is not known the precise mechanisms of UC, recent studies indicated both innate and adaptive immunity play a part in disease pathogenesis [56]. For instance, interleukin-5 (IL-5) produced by Th2-polarized $\mathrm{T}$ cells in colonic lamina propria cells, as well as IL-13 came from nonclassical natural killer $\mathrm{T}$ cells [57], were found to contribute to epithelial cytotoxicity and barrier dysfunction in UC patients. Meanwhile, the activation of neutrophils and dendritic cells, along with the expression of Toll-like receptors 2 (TLR2) and TLR4, was proved to be accumulated in colonic tissue [58-60]. Legaki et al. modified the expression of cytokines in the UC mouse model using extracellular matrix of cultured MSCs, which successfully reduced intestinal inflammation at pathological level [61]. MSCs might be able to exert protective functions by supporting colonic epithelial cells' and mucous barriers' survival and regeneration through the production of growth factors, exosomes, cytokines, and metabolites [62, 63]. They may also serve as the function of immunosuppression which could prevent the activation of effector $\mathrm{T}$ cells and promote the formation of regulatory $\mathrm{T}$ (Treg) cells [64-66]. In the past 2 years, Park et al. and Yousefi-Ahmadipour et al. have suggested that ASCs have the ability to reduce numbers of inflammatory M1 macrophages and induce differentiation of anti-inflammatory M2 macrophages to alleviate the symptoms of UC $[67,68]$. In the future, it is imperative to carry out more research on molecular mechanisms to elaborate the specific association between MSCs and UC.

Our study has certain limitations which are worthy of consideration. Primarily, parts of the enrolled studies are small-sized with low methodological quality. Plus, studies were not extensive enough owing to insufficient location sources. Additionally, we could not assess publication bias. Finally, no histopathologic or other direct indicators are evaluated to estimate the role of MSCs (such as endoscope and MRI) in human studies.

\section{Conclusion}

In conclusion, our results provide a systematic summary on efficacy of MSCs for the treatment of UC. Although MSCs appear to be potentially safe and effective in large numbers of animal and clinical trials, further randomized controlled clinical studies with high quality are needed to offer more powerful medical evidence.

\section{Additional files}

Additional file 1: Retrieval strategy. (DOCX $15 \mathrm{~kb}$ )

Additional file 2: Source of heterogeneity (Table S1, Table S2, Table S3). (DOCX 123 kb)

\section{Acknowledgements}

The present study was supported by the National Key Research and Development Program of China (No. 2016YFC1201800), the National Natural Science Foundation of China (No. 81670509), and the New Xiangya Talent Projects of the Third Xiangya Hospital of Central South University (No. 20180304).

\section{Authors' contributions}

XS designed the research, searched the lecture, and wrote the paper. QC screened and evaluated the quality of evidence, extracted the data, and helped write the paper. FW screened and evaluated the quality of evidence and extracted the data. All authors read and approved the final manuscript.

Funding

No funding.

Availability of data and materials

Availability of data and materials can be assessed both in the Material and methods section and the Results section.

Ethics approval and consent to participate

Not applicable.

Consent for publication

Not applicable.

\section{Competing interests}

The authors declare that they have no competing interests.

\section{Author details}

'Department of Gastroenterology, The Third Xiangya Hospital, Central South University, Changsha 410013, Hunan, People's Republic of China.

${ }^{2}$ Department of Dermatology, Xiangya Hospital, Central South University, Changsha 410008, Hunan, People's Republic of China. ${ }^{3}$ Department of Gastroenterology, Hunan Key Laboratory of Non-Resolving Inflammation and Cancer, The Third Xiangya Hospital, Central South University, 138 Tongzi Road, Changsha 410013, Hunan, People's Republic of China.

Published online: 23 August 2019

\section{References}

1. Fumery M, Singh S, Dulai PS, et al. Natural history of adult ulcerative colitis in population-based cohorts: a systematic review. Clin Gastroenterol Hepatol. 2018;16(3):343.

2. Torres J, Billioud V, Sachar DB, Peyrin-Biroulet L, Colombel J-F. Ulcerative colitis as a progressive disease: the forgotten evidence. Inflamm Bowel Dis. 2012;18:1356-63.

3. Høivik ML, Moum B, Solberg IC, et al. Work disability in inflammatory bowel disease patients 10 years after disease onset: results from the IBSEN Study. Gut. 2013;62:368-75

4. Molodecky NA, Soon IS, Rabi DM, et al. Increasing incidence and prevalence of the inflammatory bowel diseases with time, based on systematic review. Gastroenterology. 2012;142:46-54 e42. 
5. Ordas I, Eckmann L, Talamini M, et al. Ulcerative colitis. Lancet (London, England). 2012;380(9853):1606-19.

6. Khor B, Gardet A, Xavier RJ. Genetics and pathogenesis of inflammatory bowel disease. Nature. 2011;474(7351):307-17.

7. Kostic AD, Xavier RJ, Gevers D. The microbiome in inflammatory bowel disease: current status and the future ahead. Gastroenterology. 2014;146(6):1489-99.

8. Steel AW, Mela CM, Lindsay JO, et al. Increased proportion of CD16(+) NK cells in the colonic lamina propria of inflammatory bowel disease patients, but not after azathioprine treatment. Aliment Pharmacol Ther. 2011:33:115-26.

9. Iskandar HN, Dhere T, Farraye FA, et al. Ulcerative colitis: update on medical management. Curr Gastroenterol Rep. 2015;17(11):44.

10. Rönnblom A, Holmström T, Tanghöj H, et al. Low colectomy rate five years after diagnosis of ulcerative colitis. Results from a prospective populationbased cohort in Sweden (ICURE) diagnosed during 2005-2009. Scand J Gastroenterol. 2016;51(11):1339-44.

11. Ford AC, Achkar JP, Khan KJ, et al. Efficacy of 5-aminosalicylates in ulcerative colitis: systematic review and meta-analysis. Am J Gastroenterol. 2011;106(4): 601-16.

12. Troncone $\mathrm{E}$, Monteleone $\mathrm{G}$. The safety of non-biological treatments in ulcerative colitis. Expert Opin Drug Saf. 2017;16(7):779-89.

13. Buchman AL. Side effects of corticosteroid therapy. J Clin Gastroenterol. 2001;33(4):289-94.

14. Toruner M, Loftus EV Jr, Harmsen WS, et al. Risk factors for opportunistic infections in patients with inflammatory bowel disease. Gastroenterology. 2008;134(4):929-36.

15. Gearry RB, Barclay ML, Burt MJ, et al. Thiopurine drug adverse effects in a population of New Zealand patients with inflammatory bowel disease. Pharmacoepidemiol Drug Saf. 2004;13(8):563-7.

16. Gearry RB, Barclay ML. Azathioprine and 6-mercaptopurine pharmacogenetics and metabolite monitoring in inflammatory bowel disease. J Gastroenterol Hepatol. 2005;20(8):1149-57.

17. Kim KH, Blasco-Morente $\mathrm{G}$, Cuende $\mathrm{N}$, et al. Mesenchymal stromal cells: properties and role in management of cutaneous diseases. J Eur Acad Dermatol Venereol. 2017;31(3):414-23.

18. Le Blanc $K$, Frassoni $F$, Ball $L$, et al. Mesenchymal stem cells for treatment of steroid-resistant, severe, acute graft-versus-host disease: a phase II study. Lancet. 2008;371(9624):1579-86.

19. Duijvestein M, Vos AC, Roelofs $\mathrm{H}$, et al. Autologous bone marrow-derived mesenchymal stromal cell treatment for refractory luminal Crohn's disease: results of a phase I study. Gut. 2010;59:1662-9.

20. Forbes GM, Sturm MJ, Leong RW, et al. A phase 2 study of allogeneic mesenchymal stromal cells for luminal Crohn's disease refractory to biologic therapy. Clin Gastroenterol Hepatol. 2014;12(1):64-71.

21. Tan J, Wu W, Xu X, et al. Induction therapy with autologous mesenchymal stem cells in living-related kidney transplants: a randomized controlled trial. JAMA. 2012:307:1169-77.

22. Reinders ME, Dreyer GJ, Bank JR, et al. Safety of allogeneic bone marrow derived mesenchymal stromal cell therapy in renal transplant recipients: the neptune study. J Transl Med. 2015;13:344.

23. Zuk PA, Zhu M, Ashjian P, et al. Human adipose tissue is a source of multipotent stem cells. Mol Biol Cell. 2002;13:4279-95.

24. Meirelles LDS, Chagastelles PC, Nardi NB. Mesenchymal stem cells reside in virtually all post-natal organs and tissues. J Cell Sci. 2006;119:2204-13.

25. Shi Y, Wang Y, Li Q, et al. Immunoregulatory mechanisms of mesenchymal stem and stromal cells in inflammatory diseases. Nat Rev Nephrol. 2018; 14(8):493-507.

26. Gao WB. Effects of bone marrow-derived FLK1+CD31-CD34mesenchymal stem cells on TNBS-induced ulcerative colitis in mice. Beijing Union Med Coll. 2006. http://cdmd.cnki.com.cn/article/cdmd-1 0023-2006136358.htm.

27. Lazebnik LB, Kniazev OV, Parfenov Al, et al. The successful application of allogeneic mesenchymal stem cells in a patient with ulcerative colitis. Exp Clin Gastroenterol. 2009;4:112-5.

28. Hooijmans CR, Rovers MM, de Vries RB, Leenaars M, et al. SYRCLE's risk of bias tool for animal studies. BMC Med Res Methodol. 2014;14:43.

29. Slim K, Nini E, Forestier D, et al. Methodological index for non-randomized studies (MINORS): development and validation of a new instrument. ANZ Surg. 2003;73:712-6.

30. Wirtz S, Popp V, Kindermann M, et al. Chemically induced mouse models of intestinal inflammation. Nat Protoc. 2017;12(7):1295-309.
31. Wu XL, Tu Q, Faure G, et al. Diagnostic and prognostic value of circulating tumor cells in head and neck squamous cell carcinoma: a systematic review and meta-analysis. Sci Rep. 2016;6:202-10.

32. Higgins J, Green S. Cochrane Collaboration: Cochrane Handbook for Systematic Reviews of Interventions Version 5.1. 0. Chichester: John Wiley \& Sons Ltd and The Cochrane Collaboration; 2011.

33. Cao Y, Ding Z, Han C, et al. Efficacy of mesenchymal stromal cells for fistula treatment of Crohn' s disease: a systematic review and meta-analysis. Dig Dis Sci. 2017;62(4):851-60.

34. Niu GC. Protective roles of mesenchymal stem cells in chronic colitisassociated hepatobiliary disorders: Hebei Medical University; 2012. http:// cdmd.cnki.com.cn/Article/CDMD-11919-1012418141.htm.

35. He XW, He XS, Lian L, et al. Systemic infusion of bone marrow-derived mesenchymal stem cells for treatment of experimental colitis in mice. Dig Dis Sci. 2012:57(12):3136-44.

36. Xu X, Wang $Y$, Zhang B, et al. Treatment of experimental colitis by endometrial regenerative cells through regulation of $B$ lymphocytes in mice. Stem Cell Res Ther. 2018;9(1):146-57.

37. Park JS, Yi T-G, Park J-M, et al. Therapeutic effects of mouse bone marrowderived clonal mesenchymal stem cells in a mouse model of inflammatory bowel disease. J Clin Biochem Nutr. 2015;57(3):192-203.

38. Nam YS, Kim N, Im Kl, et al. Negative impact of bone-marrow-derived mesenchymal stem cells on dextran sulfate sodium-induced colitis. World 」 Gastroenterol. 2015;21(7):2030-9.

39. Liu W, Zhang S, Gu S, et al. Mesenchymal stem cells recruit macrophages to alleviate experimental colitis through TGF beta 1. Cell Physiol Biochem. 2015;35(3):858-65.

40. Forte D, Ciciarello M, Valerii MC, et al. Human cord blood-derived platelet lysate enhances the therapeutic activity of adipose-derived mesenchymal stromal cells isolated from Crohn's disease patients in a mouse model of colitis. Stem Cell Res Ther. 2015;6(1).

41. Knyazev O, Kagramanova A, Fadeeva N, et al. Relative frequency of relapses in patients with ulcerative colitis and Crohn's disease treated with mesenchymal stromal cells-5 years of follow-up. United European Gastroenterol J. 2017;5(5):A291.

42. Yang B, Zhao ZL, Fan Q. The effect analysis on mesenchymal stem cells for ulcerative colitis. Proc Clin Med. 2015;24(7):493-7.

43. Lazebnik L, Knyazev O, Sagynbaeva V, et al. Laboratory prediction of the effectiveness of transplantation of allogeneic mesenchymal stromal cells of bone marrow in patients with ulcerative colitis. Inflamm Bowel Dis. 2011;17:S51.

44. Liang J, Zhang H, Wang D, et al. Allogeneic mesenchymal stem cell transplantation in seven patients with refractory inflammatory bowel disease. Gut. 2012;61(3):468-9.

45. Lazebnik LB, Kniazev OV, Konopliannikov AG, et al. Allogeneic mesenchymal stromal cells in patients with ulcerative colitis: two years of observation. Exp Clin Gastroenterol. 2010;11:3-15.

46. Knyazev O, Ruchkina I, Konoplyannikov A. The efficacy and safety of allogeneic mesenchymal stromal cells in patients with ulcerative colitis. J Gastroenterol Hepatol. 2013;28:132.

47. Hu J, Zhao G, Zhang $L$, et al. Safety and therapeutic effect of mesenchymal stem cell infusion on moderate to severe ulcerative colitis. Exp Ther Med. 2016;12(5):2983-9.

48. Cao $L, X u H$, Wang $G$, et al. Extracellular vesicles derived from bone marrow mesenchymal stem cells attenuate dextran sodium sulfate-induced ulcerative colitis by promoting M2 macrophage polarization. Int Immunopharmacol. 2019;72:264-74.

49. Khan KJ, Dubinsky MC, Ford AC, et al. Efficacy of immunosuppressive therapy for inflammatory bowel disease: a systematic review and meta-analysis. Am J Gastroenterol. 2011;106(4):630-42.

50. Vickers AD, Ainsworth C, Mody R, et al. Systematic review with network metaanalysis: comparative efficacy of biologics in the treatment of moderately to severely active ulcerative colitis. PLoS One. 2016;11(10):e0165435.

51. Mueller SM, Glowacki J. Age-related decline in the osteogenic potential of human bone marrow cells cultured in three-dimensional collagen sponges. J Cell Biochem. 2001;82:583-90.

52. Stenderup K, Justuesen J, Clausen C, et al. Aging is associated with decreased maximal life span and accelerated senescence of bone marrow stromal cells. Bone. 2003;33:919-26.

53. Kern S, Eichler H, Stoeve J, et al. Comparative analysis of mesenchymal stem cells from bone marrow, umbilical cord blood, or adipose tissue. Stem Cells. 2006;24(5):1294-301. 
54. Martin Arranz E, Martin Arranz MD, Robredo T, et al. Endoscopic submucosal injection of adipose-derived mesenchymal stem cells ameliorates TNBSinduced colitis in rats and prevents stenosis. Stem Cell Res Ther. 2018;9(1):95.

55. Lightner AL, Wang Z, Zubair AC, et al. A systematic review and metaanalysis of mesenchymal stem cell injections for the treatment of perianal Crohn's disease: progress made and future directions. Dis Colon Rectum. 2018;61(5):629-40.

56. Heller F, Florian $\mathrm{P}$, Bojarski $\mathrm{C}$, et al. Interleukin-13 is the key effector Th2 cytokine in ulcerative colitis that affects epithelial tight junctions, apoptosis, and cell restitution. Gastroenterology. 2005;129:550-64.

57. Fuss IJ, Heller F, Boirivant M, et al. Nonclassical CD1d-restricted NK T cells that produce IL-13 characterize an atypical Th2 response in ulcerative colitis. J Clin Invest. 2004;113:1490-7.

58. Hanai $\mathrm{H}$, Takeuchi $\mathrm{K}$, lida T, et al. Relationship between fecal calprotectin, intestinal inflammation, and peripheral blood neutrophils in patients with active ulcerative colitis. Dig Dis Sci. 2004;49:1438-43.

59. Hart AL, Al-Hassi HO, Rigby RJ, et al. Characteristics of intestinal dendritic cells in inflammatory bowel diseases. Gastroenterology. 2005;129:50-65.

60. Fuss IJ, Neurath M, Boirivant M, et al. Disparate CD4+ lamina propria (LP) lymphokine secretion profiles in inflammatory bowel disease. Crohn's disease LP cells manifest increased secretion of IFN-gamma, whereas ulcerative colitis LP cells manifest increased secretion of IL-5. J Immunol. 1996;157:1261-70.

61. Legaki E, Roubelakis MG, Theodoropoulos GE, et al. Therapeutic potential of secreted molecules derived from human amniotic fluid mesenchymal stem/ stroma cells in a mice model of colitis. Stem Cell Rev. 2016:12(5):604-12.

62. Hu J, Zhang L, Wang N, et al. Mesenchymal stem cells attenuate ischemic acute kidney injury by inducing regulatory $T$ cells through splenocyte interactions. Kidney Int. 2013;84(3):521-31.

63. Hoshino A, Hashimoto $\mathrm{H}$, Arihiro $\mathrm{S}$, et al. Tenascin-c mediates the suppressive effects on inflammation by the mesenchymal stem cell in dextran sulfate sodium induced colitis. Gastroenterology. 2015;148(4):S547.

64. Ma S, Xie N, Li W, et al. Immunobiology of mesenchymal stem cells. Cell Death Differ. 2014;21(2):216-25.

65. English K. Mechanisms of mesenchymal stromal cell immunomodulation. Immunol Cell Biol. 2013;91:19-26.

66. Hou R, Li J, Niu X, et al. Stem cells in psoriasis. J Dermatol Sci. 2017:86:181-6.

67. Yousefi-Ahmadipour A, Rashidian A, Mirzaei MR, et al. Combination therapy of mesenchymal stromal cells and sulfasalazine attenuates trinitrobenzene sulfonic acid induced colitis in the rat: the S1P pathway. J Cell Physiol. 2019; 234(7):11078-91

68. Park HJ, Kim J, Saima FT, et al. Adipose-derived stem cells ameliorate colitis by suppression of inflammasome formation and regulation of M1macrophage population through prostaglandin E2. Biochem Biophys Res Commun. 2018;498(4):988-95.

\section{Publisher's Note}

Springer Nature remains neutral with regard to jurisdictional claims in published maps and institutional affiliations. 